\title{
Colonialism, justice and the rule of law: a Southern African and Australian narrative
}

\author{
Sascha Dominik Bachmann* \\ Assessor Juris (LMU, Germany), LLM (Stell), LLD (UJ) \\ Reader in Law, Lincoln Law School, University of Lincoln \\ Tom Frost \\ LLB (Hons)(Leic), PhD (Soton) \\ Lecturer in Law, Newcastle Law School, Newcastle University
}

\section{OPSOMMING \\ Kolonialisme, geregtigheid en die oppergesag van die reg: 'n Suider-Afrikaanse en Australiese verhaal}

Kolonialisme het 'n groot impak op die regstelsels van lande regoor die wêreld gehad. Die historiese impak van die Britse Ryk kan vandag nog steeds gevoel word in lande so uiteenlopend soos Australië en Suid-Afrika. Hierdie impak word in beide hierdie lande ondersoek, in sowel sy historiese vorm van rassediskriminasie, as die moderne gevolge van die koloniale verlede. Hierdie artikel ontleed hoe formele opvattings van die oppergesag van die reg en regsekerheid, pogings om geregtigheid vir gedane historiese onreg te bewrkstellig, kan ondermyn. Voorbeelde hiervan kan gevind word in die Aboriginal grondregte litigasie in Australië, sowel as litigasie in die Verenigde State van Amerika onder die Alien Tort Act.**

\section{Introductory Remarks}

Writing after the fall of the Berlin Wall, Fukuyama posited the "end of history", the universalisation of Western liberal democracy as the final form of human government. ${ }^{1}$ Western liberal democracy has at its heart the ideas of equal treatment under the law, individual rights and the rule of law. Underpinning this is the idea of legal certainty - that the law must be certain in order to ascertain rights and duties that are applied equally to all. ${ }^{2}$ However, the history of Western liberal democracy is inextricably linked to European colonialism. Indeed, the history and implications of the rise of liberal democracy in Europe, to be understood properly, must be read in conjunction with this colonial heritage.

Liberal democracy's development took place in this shadow; the legal systems of many countries around the world bear witness to this intertwined history. It is this intertwined relationship which gives rise to

* Sascha Dominik Bachmann undertook some prior work in the field of Human Rights Litigation and Historical Claims Remedies while working as a Postdoctoral Research Fellow with the University of Johannesburg before joining the University of Portsmouth, UK, in 2008 and moving to the University of Lincoln in 2012.

* The authors thank Mrs Sasha-Lee Afrika, LLB, LLM for the Afrikaans translation.

1 Fukuyama The End of History and the Last Man (1992).

2 Radbruch Legal Philosophy (1932) 112. 
a dilemma: the imposition of a legal order defines empire and colonialism; the foundation of an independent legal order marks the birth of the newly independent nation. The law serves both these masters. ${ }^{3}$ In a real sense, the ideal of the rule of law played a huge part both in the colonial imposition of a legal order, as well as the foundation of an independent legal order after independence.

This article explores this paradox. Two main arguments are put forward. Firstly, it is contended that formal interpretations of the rule of law and equality have historically served to perpetuate oppression and discrimination within a colonial context. This argument is supported through reference to examples of British colonialism in Southern Africa and Australia.

This second argument is connected to what is called here "historical justice litigation", litigation which has at its aim the rectifying of past oppression in colonial (now postcolonial) states. What is so interesting about this litigation is its attempt to reconcile belief in the rule of law and its qualities with an attempt to provide justice for the victims of oppression. In this way, the law is very much attempting to serve its two masters. It is in this Janus-faced existence that this litigation proceeds, heading to an uncertain future.

\section{The Rule of Law}

In a sense, this article is challenging the rule of law. The phrase "in a sense" is used here because historical justice litigation is marked by an adherence to the self-same doctrine, although it is a substantive, rather than a formal interpretation of the "rule of law" which is adhered to. As Paul Craig has maintained, the dichotomy between formal and substantive conceptions of the rule of law is crucially importance in determining the nature of the specific legal precepts which can be derived from it. ${ }^{4}$

The importance of this distinction can be seen through an example of a United Kingdom statute, the Constitutional Reform Act 2005 (CRA). Amongst other things, the CRA provided for the new United Kingdom Supreme Court, replacing the Judicial Committee of the House of Lords. In prefacing the subsequent constitutional changes (the exact content of which are not strictly relevant here), section 1 states:

This act does not adversely affect -

(a) the existing constitutional principle of the rule of law. ${ }^{5}$

3 Douzinas \& Gearey Critical Jurisprudence: The Political Philosophy of Justice (2005) 283.

4 Craig "Formal and Substantive Conceptions of the Rule of Law: An Analytical Framework" 1997 Public Law 467.

5 S 1 (c 4) Constitutional Reform Act 2005 (UK). 
What the CRA shows is that the rule of law is central to the operation of the law in the UK. What the Act does not do is define the rule of law. The term appears so self-evident that it seems to need no definition. This appears plausible at first glance; there are a number of judgments in British courts where judges have invoked the rule of law as justification for their rulings. ${ }^{6}$

Nor is this lack of meaning restricted to the United Kingdom. Waldron, commenting upon Bush $v$ Gore $^{7}$ in the United States Supreme Court, noted that the rule of law was invoked by both parties' legal teams to support their cases. Waldron's impression was that the use of this phrase meant little more than "Hooray for our side!"8 Perhaps Tamanaha is right when he described the rule of law as "an exceedingly elusive notion" that gives rise to a "rampant divergence of understandings" and is in fact analogous to the notion of the "good" in the sense that "everyone is for it, but have contrasting convictions about what it is". 9

However this lack of definition brings to the fore the importance of whether the rule of law is given substantive or formal meaning. Formal conceptions of the rule of law address the manner in which the law was promulgated, the clarity of the ensuing norm and whether the norm was promulgated prospectively or retrospectively. ${ }^{10}$ Such conceptions do not seek to pass judgment upon the actual content of the law itself. This can be contrasted to substantive conceptions of the rule of law, which seek to develop certain substantive rights which are claimed to derive from, or be based upon, the rule of law. The rule of law founds these rights, which can be used to distinguish between "good" laws which comply with such rights, and "bad" laws which do not. ${ }^{11}$

The potential difficulties of establishing substantive conceptions of rights and duties can be illustrated with reference to the doctrines of substantive and procedural due process in US Constitutional Law. Substantive due process asks the question, under the due process clause of the Fourteenth Amendment, of whether the government's deprivation of a person's life, liberty or property is justified by a sufficient purpose. Procedural due process asks whether the government has followed the proper procedures when it takes away life, liberty or property. ${ }^{12}$ However, Supreme Court opinions have never defined substantive due process, which looks to whether there is a sufficient substantive

$6 \quad R v$ Horseferry Road Magistrates' Court, ex parte Bennett 19941 AC 42 (HL) 62, 64 (Lord Griffiths), 67 (Lord Bridge), 75-77 (Lord Lowry); A v Secretary of State for the Home Department 20052 AC 68 (HL) par 42 (Lord Bingham), par 74 (Lord Nicholls).

7 Bush v Gore 531 US 98.

8 Waldron "Is the Rule of Law an Essentially Contested Concept (in Florida)?" in The Rule of Law and the Separation of Powers (ed Bellamy) (2005) 119.

9 Tamanaha On the Rule of Law (2004) 3.

10 Craig 467.

11 Ibid 467-468.

12 Chemerinsky "Substantive Due Process" 1999 Touro LR 1501. 
justification or a good enough reason for such a deprivation to occur; it is a contextual standard. ${ }^{13}$

Chemerinsky provides an example to illustrate the divergence between both approaches. Under the Fourteenth Amendment, the word "liberty" has been held to provide to parents a fundamental right to the custody of their children. ${ }^{14}$ In this context, procedural due process requires the government to give notice and a hearing before it can permanently terminate custody. ${ }^{15}$ Contrarily, substantive due process requires the government to show a compelling reason that would demonstrate an adequate justification for terminating custody. ${ }^{16}$ Procedural due process gives no wider guarantee for "fairness" beyond the requirement that the correct procedures are followed. Substantive due process appears much more intangible than procedural due process, and cannot be easily or succinctly described. The content of substantive due process is driven more by Rawlsian conceptions of "fairness" than by any exhaustive list of attributes. ${ }^{17}$

The tension between procedural and substantive viewpoints is exacerbated in respect of the rule of law. For instance, Raz has commented upon the tendency to use the rule of law as a shorthand description of the positive aspects of any given political system. ${ }^{18}$ Finnis finds himself with a similar definition of the rule of law. Finnis describes the rule of law as "the name commonly given to the state of affairs in which a legal system is legally in good shape". ${ }^{19}$

Even here the content of this foundational legal concept will differ greatly depending upon whether a procedural or substantive viewpoint is adopted. This is the case as there are certain principles which can be posited as forming part of the rule of law. The most important can be said to be the principle that all persons are to be treated equally under the law. Paine perhaps explained it best:

That in America THE LAW IS KING. For as in absolute governments the King is law, so in free countries that law ought to be King; and there ought to be no other. ${ }^{20}$

The implications of this principle, equal treatment under the law, differ depending on whether formal or substantive definitions of equality are adopted. Formal equality is as old a principle as Western political philosophy: if two persons have equal status in at least one normatively

\footnotetext{
13 Ibid 1501.

14 Santosky v Kramer 455 US 745753.

15 Lassiter v Department of Social Services 452 US 1827.

16 Santosky supra 762.

17 Rawls A Theory of Justice (1999).

18 Raz The Authority of Law: Essays on Law and Morality (1979) 210 (Ch 11 "The Rule of Law and its Virtue").

19 Finnis Natural Law and Natural Rights (1980) 270.

20 Paine Common Sense (1994) 279.
} 
relevant respect, they must be treated equally with regard to this respect. As Aristotle stated, we are to "treat like cases alike". 21

However, it is an emphasis upon formal equality which is argued to characterise historical colonial discrimination in both Southern Africa and Australia. Successive colonial measures adopted a very narrow procedural, formal conception of the rule of law and equality; indigenous populations were not treated as having equal status in normatively relevant respects, which justified a discriminatory regime being applied favouring non-indigenous peoples.

The main objection to be drawn here is that the focus upon procedure meant that the original racist attitudes which underpinned discrimination did not get challenged. Historical justice litigation can be read in a way which seeks to disturb such thinking and assumptions.

\section{The Savage Economy of Jurisprudence}

Historical justice litigation is marked by an acute historical sense. This emphasis upon history requires us to engage with the intellectual premises of colonial law-making. ${ }^{22}$ The notion that a colonial country is imbued with "primitive" law and it is the "gift" of the law of the coloniser becomes, for Douzinas and Gearey, ${ }^{23}$ one of the central justifications for the colonial state.

Fitzpatrick $^{24}$ has shown that the distinction between the savage and the civilised has historically run through English jurisprudence. There is created a European identity, opposed to the figure of a pre-modern savage who inhabits a pre-modern world. The savage must be "civilised" through the imposition of civilised, European law. This mindset is illustrated in the Privy Council decision of In re Southern Rhodesia, ${ }^{25}$ where Lord Sumner argued that:

The estimation of the rights of aboriginal tribes is always inherently difficult. Some tribes are so low in the scale of social organisation that their usages and conceptions of rights and duties are not to be reconciled with the institutions or the legal ideas of civilised society. Such a gulf cannot be bridged. It would be idle to impute to such people some shadow of the rights known to our law and then to transmute it into the substance of transferable rights of property as we know them.

Such a mindset ran through British colonialism in Australia in the eighteenth and nineteenth centuries.

21 Aristotle Nicomachean Ethics (1984) Book 531131 a10-b15.

22 Douzinas \& Gearey 286.

23 Ibid.

24 Fitzpatrick The Mythology of Modern Law (1992) 65.

251919 AC 211 (HL) 233-234. 
As French and Lane explain, ${ }^{26}$ the indigenous people of the Australian continent were long thought of as wandering tribes, who were "living without certain habitation and without laws". 27 The Australian colonies were almost universally seen as "settled" rather than "conquered"; the lands of modern day New South Wales were deemed "uninhabited" by civilised peoples and therefore in no way could be conquered. This was confirmed in the case of Cooper v Stuart ${ }^{28}$ in 1889 :

The extent to which English law is introduced into a British Colony, and the manner of its introduction, must necessarily vary according to the circumstances. There is a great difference between the case of a Colony acquired by conquest or cession, in which there is an established system of law, and that of a Colony which consisted of a tract of territory practically unoccupied, without settled inhabitants or settled law, at the time when it was peacefully annexed to the British dominions. The Colony of New South Wales belongs to the latter class.

McNeil $^{29}$ argued that the Privy Council reached its conclusion about the absence of any system of Aboriginal law without any evidence of the nature of Aboriginal society. Cooper $v$ Stuart $^{30}$ fits the traditional narrative; namely that Australia was claimed by the British Crown under the legal doctrine of terra nullius, literally 'no man's land'.

The historian Reynolds has been very influential in disseminating this view. ${ }^{31}$ For Reynolds, land rights for Aboriginals were recognised in the nineteenth century by the Imperial Colonial Office in London. ${ }^{32}$ It was the settlers, governments and courts in the colonies that ignored land rights in defiance of the law. ${ }^{33}$ For this traditional narrative, terra nullius was a misconception, masking the fact that Aboriginals were recognised as having rights. This can be supported - in 1836, the case of $R \mathrm{~V}$ Murrel $P^{4}$ extended to Aboriginal people the right to be subject to the laws of the colony. Essentially, Reynolds contended that Aboriginal dispossession was simply a mistake; ${ }^{35}$ this way of thinking assumes that if Australia had not been classified as terra nullius in 1788 Aboriginals would have had legal rights. ${ }^{36}$ Thus if terra nullius could be overruled, the legal system of Australia could be "healthy once more". 37

26 French \& Lane "The Common Law of Native Title in Australia" 2002 Oxford U Commonwealth LJ 16.

27 MacDonald v Levy (1833) 1 Legge 3945 (NSWSC).

28 Cooper v Stuart (1889) 14 App Cas 286 (PC) 291.

29 McNeil Common Law Aboriginal Title (1989) 122.

30 Cooper v Stuart (1889) 14 App Cas 286 (PC) 291.

31 Reynolds The Law of the Land (1987).

32 Ibid 97-103.

33 Ibid 140.

$34 \quad R$ v Murrell (1836) 1 Legge 72 (NSWSC).

35 Reynolds 230.

36 Ritter "The Rejection of Terra Nullius in Mabo: A Critical Analysis" 1996 Sydney LR 28-29.

37 Ibid 29. 
Despite this narrative, no case ever stated that Australia was terra nullius. ${ }^{38}$ The reason for this was simple: Aboriginal land rights were not denied on the basis of a legal doctrine, but rather upon the operation of power. Terra nullius is a title for the discourses of power which operated to legitimate the dispossession of Aboriginal peoples. ${ }^{39}$ The founding ideals of the Enlightenment led to a colonial mindset which favoured "progress". ${ }^{40}$ This sense of progress led to a desire to civilise the "savage". Colonial powers expressed their identity through the denigration of those who were perceived to be "unlike" themselves and could be subjected to that civilising process. ${ }^{41}$

Thus the Australian Aboriginals, regarded as "low in the scale of social organisation", and their occupancy of land were ignored in considering the title to land in a settled colony. ${ }^{42}$ Nor did Aboriginals only lack legal rights to land. As the legal historian Neal has stated, "as a practical matter, the Aborigines stood outside the protection of the rule of law". 43 The absence of legal rights for Aboriginals was a self-evident truth. The internal ideological mechanisms of the law meant Aboriginal people were labelled as non-conformists, and denied the law's benefits. "44 "Like persons" were treated "alike"; however, Aboriginals were not "alike" to Europeans, and therefore not to be treated equally under the law. There are echoes of Plessy $v$ Ferguson ${ }^{45}$ and the "separate but equal" decision of the US Supreme Court.

An example of this can be found in 1842 in South Australia, where several Aboriginal men and women were hung extra-judicially after being suspected of murder. The Governor of South Australia, Governor Gawler, requested an opinion from Cooper CJ of the South Australian Supreme Court in response to public protests over the hangings "on the amenability of the Aborigines to European law". ${ }^{46}$ Cooper CJ replied:

It is impossible to try according to the forms of English law people of a wild and savage tribe whose country, although within the limits of the Province of South Australia, has never been occupied by Settlers, who have never submitted themselves to our dominion. ${ }^{47}$

Ultimately, it was the civilised, European conception of the rule of law which was imposed on all persons in Australia. The whole of native

38 Ibid 9.

39 Ibid 12

40 Douzinas \& Gearey 287.

41 Douzinas \& Gearey 287; Fitzpatrick 70.

42 Mabo v Queensland (No 2) 1992175 CLR 1 (HCA) par 39.

43 Neal The Rule of Law in a Penal Colony: Law and Politics in Early New South Wales (1991) 17.

44 Ritter 11.

45 Plessy v Ferguson 163 US 537.

46 Watson "Buried Alive" (2002) Law and Critique 262.

47 Castles An Australian Legal History (1982) 524-525; Smandych "Contemplating the Testimony of 'Others': James Stephen, the Colonial Office, and the Fate of Australian Aboriginal Evidence Acts, Circa 18391849” 2004 Australian J of Legal History 237. 
society was seen as deviant, or potentially deviant. ${ }^{48}$ The laws of Australian governments were made for the common good and for the benefit of the common man. However, historically the common man had been the non-Aboriginal man, and excluded the Aboriginal man. ${ }^{49}$

\section{The Stolen Generations in Australia}

After the British settlement of the Australian continent in 1788, until the mid-nineteenth century, European policy toward Aboriginals was fundamentally genocidal. ${ }^{50}$ The policy of dispossession, contributing to the decline of the Aboriginal population, led to a view that Aboriginals were a "dying race", with extinction a certainty in the face of the robust and supreme European way of life. ${ }^{51}$ However, by the end of the nineteenth century, it became clear that traditional Aborigines were not going extinct. In addition, a large amount of sexual contact between Aboriginal and non-Aboriginal populations had produced a growing mixed-race population, referred to as the problem of the "half-caste":

There was a growing realisation that the descendants of a dying race might continue to haunt a White Australia for generations. ${ }^{52}$

This led to a State-wide program to eliminate Aboriginality, and in turn protect civilisation, represented by White Australia. ${ }^{53}$ Robert van Krieken saw two elements to this civilising offensive: first, regulation of the case of the problem, the sexual intercourse between whites and blacks, through "protective" legislation. 54 As a result, Australian Aborigines were subject to a huge degree of regulation, governing their sexual relations, marriage, employment, income, property ownership, education and custody of their children. ${ }^{55}$ The aim was to quarantine white and "mixed-bloods" from "full-blood" Aborigines, to allow the fullblood group to continue down the path of extinction. ${ }^{56}$

Secondly, Australia made use of the pre-existing social technology which had been in place in Europe since the sixteenth century for dealing

48 Fitzpatrick 111.

49 Department of the Parliamentary Library Information and Retrieval System, "Pat Dodson: Mabo, Reconciliation and National Leadership", National Press Club, 15 September 1993 (http://hdl.handle.net/10070/91167 (accessed on 2012-04-23)).

50 Van Krieken "The barbarism of civilisation: cultural genocide and the "stolen generations”" 1999 British J of Sociology 303.

51 McGregor Imagined Destinies: Aboriginal Australians and the Doomed Race Theory, 1880-1939(1997).

52 Ibid 134.

53 Blackton "The dawn of Australian national feeling, 1850-56" 1955 Pacific Historical Rev 121-138.

54 Van Krieken 305.

55 O’Malley “Gentle genocide: the government of Aboriginal peoples in Central Australia” 1994 Social Justice 48.

56 Moran "White Australia, Settler Nationalism and Aboriginal Assimilation" 2005 Australian J of Politics and History 168-193. 
with the problems of social discipline of the working classes. The removal of Aboriginal children from their parents was based upon pre-existing practices concerning unacceptable "problem" groups in Western Europe - in this way, the rule of law was being maintained; Aboriginals were not considered "equal" to Europeans, and therefore could justifiably be treated differently. Legislation was passed which made the State, rather than the parents, the legal guardian of all Aboriginal children. By the 1930's, any child of Aboriginal descent could be removed from their family and placed in a government institution to be trained in ways of "civilisation". 57

The Human Rights and Equal Opportunity Commission's Bringing Them Home Report in 1997 estimated that between 1910 and 1970 between one in three and one in ten Aboriginal children were removed from their parents. ${ }^{58}$ The ultimate aim of White Australia was to "absorb" or "assimilate" Aboriginal Australia, an aim motivated by knowledge of the eventual destruction of Aboriginal culture and a humanitarian concern to civilise Aboriginals: "Europeanisation is inevitable". 59

It was not until 1967 that Aboriginals were included in the Australian census for the first time, and it took until 1969 for all Australian States to repeal the legislation allowing for the removal of Aboriginal children under the policy of "protection". In short, the pervading discourse changed in Australia. When Aboriginals started to bring cases claiming rights to dispossessed lands the Courts were faced with a dilemma: why had the judiciary not protected Aboriginal land rights for the first 183 years of white settlement? ${ }^{60}$ In answering this question, the Australian Courts utilised the very principle of the rule of law, but in a way which could further entrench this historical repression. Such a move could cast doubt upon the efficacy of future historical justice litigation within Australia.

\section{A Short Overview of Britain's Impact on South Africa's Apartheid Policies}

\section{South Africa - a Triangle of British, Boer and Black Conflict and Concession}

Just as in Australia, British colonialism also had a huge impact in defining forms of belonging in South Africa. South Africa's racial policies have to

57 Van Krieken 305; Haebich For Their Own Good: Aborigines and Government in the Southwest of Western Australia, 1900-1940(1988) 350.

58 Human Rights and Equal Opportunity Commission "Bringing Them Home: Report of the National Inquiry into the Separation of Aboriginal and Torres Strait Islander Children from their Families" (1997) http://www.austlii. edu.au/rsjlibrary/hreoc/stolen/index/html (accessed on 2012-04-23).

59 Berndt \& Berndt From Black to White in South Australia (1952) 275.

60 Ritter 27. 
be studied before the backdrop of its history of conflict among its many peoples, tribes or nations. This is first a struggle between white British and the "Boer", 61 as the new nation of "Afrikaners" was referred to, later a struggle between "white" South Africans and black South Africans. South Africa is marked by a triangle of ethnic, cultural and racial conflict and compromise. ${ }^{62}$

The arrival of Jan van Riebeek, a young Dutch employee of the Dutch East India Company at Table Bay in April 1652, marked the beginning of a permanent white presence and, up to 1994, dominance in a region which was to become South Africa. It also marked the beginning the Afrikaner or Boers, who developed into a distinct nation of white Afrikaans speaking people.

The history of the South African people is rich in symbolic events of ethnic collective suffering which shaped the identity of its people, influenced their actions and continues to exert its influence to this day. For the Afrikaners, the Boer War at the turn of the twentieth century constitutes one such event. ${ }^{63}$ The British decision to establish "concentration camps" for interning non-combatant family members of the Afrikaner "Boer" commandos during the Boer War of 1899-1902 led to the death of more than 20,000 Boer women and children in some 66 camps. ${ }^{64}$ This invention by the British military high command, together with the applied tactics of "scorched earth" as a punitive means of fighting an asymmetric campaign of guerrilla warfare shaped Afrikaner identity. It ultimately gave rise to Afrikanerdom, a new nationalistic and religious identity among South Africa's white Afrikaners, ${ }^{65}$ and fuelled a conception of the British as a past and sometimes present enemy. ${ }^{66}$

The establishment and implementation of Apartheid as official state policy and the victimisation of the African majority after 1948 have, at least partly, their roots in this British-Boer conflict. Afrikaner identity

61 Giliomee 34-35, for a description of the Boer "race"; the term is not used derogatively in the context of the article.

62 Giliomee The Afrikaners -Biography of a People (2009) for an authoritative and uncompromising overview of the South African history from the perspective of the white Afrikaner minority; Leach South Africa (1986) for an contemporary account of South Africa's apartheid and its violent challenges during the last decade of its white minority rule; Welsh The Rise and Fall of Apartheid (2009) for an informative and comprehensive account of the rise and fall of Apartheid.

63 Van Jaarsveld Lewende Verlede (1961) 68-69; 73-74 for an analysis of Afrikaner history and ideology.

64 Leach 31 who numbers the total number of Boer concentration camp victims at 26,000. Africans who also fought on the side of the Boers and who were also subjected to internment suffered a similar fate with high mortality numbers in the British camps, see Pakenham The Boer War (2007) 510.

65 Van Jaarsveld 66-67 for a description of Afrikaner identity.

66 A sentiment which sometimes still resonates today and found its way into contemporary Pop culture as the success of the singer Bok van Blerk shows who landed a hit in 2006 with his rendition of "De La Rey", which commemorates the above British atrocities and calls for Boer unity. 
transcended its own victimisation in the camps towards the justification for own human rights violations in the wake of Apartheid. ${ }^{67}$

African and other "Non-White"68 suffering under post-1948 Apartheid and suppression can be best summarised in former President De Klerk's apology, which highlighted the daily plights, violations and humiliations, which non-white South African citizens had to endure:

I apologise in my capacity as leader of the NP to the millions who suffered wrenching disruption of forced removals; who suffered the shame of being arrested for pass law offences; who over the decades suffered the indignities and humiliation of racial discrimination. ${ }^{69}$

Apart from such omnipresent discrimination and victimisation, two particular events in history exemplify the brutality of the Apartheid regime: the "Sharpeville shootings" of $1960,{ }^{70}$ when South African police opened fire on black demonstrators and killed 69 people, and the Soweto uprising of 16 June $1976 .^{71}$ South Africa's Apartheid policies of institutionalised discrimination and persecution of its non white people cannot be isolated from these forming historical events.

\section{Apartheid}

Apartheid, ${ }^{72}$ the system of racial segregation in South Africa, would today qualify as not only a state delict/tort, a violation of a state's international obligation of a peremptory nature, ${ }^{73}$ but also as one of the four core crimes of international criminal law, the international crime against humanity. ${ }^{74}$ The South African system of Apartheid was not an invention by the Afrikaners, nor unique in 20th century's policies of

67 Giliomee xiv, recognises the Afrikaner as "both victims and proponents of European imperialism".

68 Such as the "Coloured" (mixed race) and Indian race groups.

69 "De Klerk Apologises Again For Apartheid" South African Press Association (1997-05-14) http://www.justice.gov.za/trc/media/1997/9705/s970514a.htm (accessed on 2012-04-23).

70 Welsh 72-73; SAHO at http://www.sahistory.org.za/topic/sharpevillemassacre-21-march-1960 (accessed on 2012-04-20) offers a wide variety of online sources. Sharpeville township was once more in the headlines in 1984 when civil unrest erupted.

71 Also known as the Soweto Youth Riot, which spread over the whole country and were only contained in October 1977 . There was a repeat of these riots in Soweto and Sharpeville in 1984 - Leach 128ff. See Welsh 101-102 for an account of the divergent Afrikaner opinion on the Soweto 1976 shootings. Both events serve as manifestations of the will of the black majority to take active action against white minority rule, action which moved away from passive resistance to out and out protest and even armed struggle.

72 Coined on the Afrikaans "Apartness".

73 Part (4) of the Commentary to Article 40 of the ILC Draft Articles on State Responsibility, Yearbook of the International Law Commission 2001 vol II Part Two, where racial discrimination and apartheid are listed as potential peremptory norm violations of international law.

74 Article 7 Part 1 of the Statute of the International Criminal Court, where the crime of apartheid is listed as one of the elements of crimes against humanity, lit (j); See Article 5 of the Statute of the International Tribunal for 
racial segregation: what made Apartheid different from other examples of racial segregation, discrimination and hate past and present was that it systematically institutionalised a legal framework for such treatment.

The Nationalist Party which came to power in 1948 established a legal framework of an institutionalised system of racial discrimination and exclusion, second only to the example of Nazi Germany's race legislation, highlighted by the Nürnberger Gesetze, or Nuremberg Laws of $1935 .{ }^{75}$ Apartheid legislation governed the fields of racial segregation, jobs and employment, political rights and freedoms, citizenship, land and property rights, education and freedom of movement. ${ }^{76}$ It fell to the courts of South Africa to enforce Apartheid law: the judiciary became a trusted pillar in enforcing Apartheid's law and policies. ${ }^{77}$ This "top to bottom" enforcement was supplemented by a broad based implementation which allowed for "flexible" oppression - the white minorities were active stakeholders in such oppression. ${ }^{78}$ Consequently, Apartheid did not require the availability of security and police assets in exceptional high numbers. ${ }^{79}$

The legal foundations of apartheid were British in origin and nature: while Britain can be credited with having ended slavery and slave trade in the Cape during the 1830 's, ${ }^{80}$ it also laid the legal foundations of social domination and racial segregation through legislation. In 1856, the first Masters and Servants Act came into force, ${ }^{81}$ which was used to deny collective social rights to unskilled workers and was basically used to regulate African labour relations. Such social racial segregation was enhanced by further subsequent legislation, such as the Franchise and Ballot Act of $1892 .^{82}$

the Former Yugoslavia, 1993-05-25, UNSC Res 827 (1993) which criminalises racial discrimination as crimes against humanity.

75 The Nuremberg Laws of 1935. The "Law for the Protection of German Blood and German Honour" and the "Reich Citizenship Law" stripped German Jews of their national identity and restricted interracial social as well as professional interaction, establishing the first prerequisite for the later Shoah.

76 Truth and Reconciliation Commission of South Africa Report Volume 1 ch 13 http://www.justice.gov.za/trc/report/finalreport/Volume\%201.pdf (last accessed 2012-04-24) for a detailed overview of all major apartheid legislation within a topical context.

77 Welsh 74-75; reference is also made to the Treason Trial from 1956-1961 which resembled one of the last 'fair' trials where the rule of law was still upheld.

78 Referring to white Afrikaners as well as English speaking South Africans.

79 Giliomee 551-552.

80 With Emancipation Day on 1 December 1838 marking an early "freedom" day in South African history.

81 This Act forms part of a wider legislative effort in the UK (and its territories) to regulate relationships between employers and employees; the last of these Acts was passed in 1904.

82 Effectively limiting the African vote by tying it to financial and educational minimum requirements. 
The creation of the Union of South Africa also saw the first legal enshrinement of racial segregation policies. The Natives Land Act ${ }^{83}$ prohibited Africans from owning land outside designated reserves, laying the foundations for post 1948's Apartheid's Homeland or "Bantustan" policies.

South Africa's past serves as a case study of the changing role of perpetrator and victimhood: the legislative measures taken by the British authorities pre-1948, in concert with British colonial rule which saw its fair amount of ruthlessness in Southern Africa, meshed together with the widespread Afrikaner perception that own victimhood could be used to justify own wrongs. ${ }^{84}$

\section{The Role of Historical Justice Claims in Remedying the Past}

\section{Introduction}

Human rights litigation contributes to an important long-term objective: working toward a world in which those who commit gross violations of human rights are brought to justice swiftly, in whatever country they try to hide. ${ }^{85}$

Historical justice litigation has lofty aims: namely the addressing of historical wrongs ranging from slavery, crimes against humanity and genocide. Such litigation encompasses a substantive vision of the rule of law: that equal treatment under the law includes redress for past wrongs, and that justice is as important a part of the rule of law as legal certainty. However, it is in running into formal conceptions of the rule of law that such litigation has stumbled in the courts.

Two approaches to such litigation are considered: the "extraterritorial" approach and the "territorial" approach. The extraterritorial approach involves the bringing of litigation in countries not connected to the original human rights violation; the focus here will be upon cases brought in the United States under the Alien Tort Statute (ATS). The territorial approach focuses upon litigation brought within the same territory as the original human rights violation. The Australian land rights litigation provides an example of this.

It is the way in which the rule of law has been interpreted by courts that potentially calls into question whether historical justice claims can provide justice to the victims of human rights abuses. Only by addressing this challenge can such litigation fulfil its potential to supplement the other existing forms of human rights protection available in International Law and to protect human rights.

8327 of 1913.

84 Van Jaarsveld 64.

85 Stephens International Human Rights Litigation in US Courts (2008). 


\section{ATS Litigation}

The rise in extraterritorial historical justice litigation cases in the courts of the US was well documented since the 1990 's. ${ }^{86}$ This modern litigation began in 1980, when the US Court of Appeal for the Second Circuit decided in the seminal case of Filártiga $v$ Pena-Irala that acts of torture committed among non-US citizens outside of the USA could establish jurisdiction of US federal courts. ${ }^{87}$

The Second Circuit based its decision on the ATS, also referred to as the Alien Tort Claims Act, or ACTA. The ATS was part of the federal Judiciary Act 1789. Today, its original meaning and purpose are uncertain. ${ }^{88}$ Indeed, even the ATS itself is short:

The district courts shall have original jurisdiction of any civil action by an alien for a tort only, committed in violation of the law of nations or a treaty of the United States. ${ }^{89}$

The ATS remained almost unutilised for human rights protection until Filartiga. This is not to state that the ATS was redundant; it was used as the basis for a child custody suit between aliens, ${ }^{90}$ as well as determining title to slaves on board an enemy vessel taken on the high seas. ${ }^{91}$

The plaintiffs in Filártiga, in using the ATS to bring the alleged torturer in question to justice, opened up the possibility of using the ATS to pursue human rights violations across the world. Since 1980, the ATS has been used by plaintiffs to initiate legal actions against other individuals and in some instances, even states, ${ }^{92}$ as perpetrators of human rights violations. Thus the ATS opens up the possibility of pursuing a substantive conception of the rule of law, where all violators of human rights can be brought to justice, and impunity does not reign.

ATS litigation in the US provides one of the few extraterritorial opportunities for natural persons to seek redress for human rights violations. Since 2000, ATS litigation has been brought against Multi-

86 Ibid 541-548; Anderson “Redressing Colonial Genocide: The Hereros' Cause of Action Against Germany" 2005 California LR 1155; Sarkin \& Fowler "Reparations for Historical Human Rights Violations: The International and Historical Dimensions of the Alien Torts Claims Act Genocide Case of the Herero in Namibia” 2008 Human Rights Rev 331.

87 Filartiga $v$ Pena-Irala $630 \mathrm{~F} 2 \mathrm{~d}$ 876. The ATCA/ATS was only used on a few occasions prior to Filartiga; Symposium "Corporate liability for violations of international human rights law" 2001 Harvard LR 2033.

88 D'Amore "Note, Sosa V Alvarez-Machain and the Alien Tort Statute: How Wide Has the Door to Human Rights Litigation Been Left Open?" 2006 Akron LR 596.

8928 USC § 1350.

90 Adra v Clift 195 F Supp 857.

91 Bolchos v Darrel 3 Fed Cas 810.

92 Such as terrorism, Smith v Socialist Peoples Libyan Arab Jamahiriya 101 F 3d 239 for the terrorist Lockerbie bombing of 1988 
National Companies (MNC's). ${ }^{93}$ This development should not surprise. The laws of the US hold that:

In determining the meaning of any Act of Congress ... the words "person" and "whoever" include corporations, companies, associations, firms, partnerships, societies, and joint stock companies, as well as individuals. ${ }^{94}$

Corporations have also been given rights under the First Amendment, relating to political speech, 95 and the Fourteenth Amendment, guaranteeing equal treatment under the law. ${ }^{96}$ Thus such ATS cases against corporations seem to be making a broader point: namely that the ATS does apply to corporations and that if the Supreme Court extends constitutional protections to corporations, then corporations should also have duties, and can be held liable for breaching these. There have been ATS cases brought against corporations for their alleged collusion in crimes against humanity, war crimes and torture. ${ }^{97}$

What has been forwarded by plaintiffs is a substantive conception of the rule of law, incorporating the adherence of basic human rights norms. ATS plaintiffs appear to view the rule of law as protecting against human rights violations. However, this vision has not been uncritically accepted by US courts.

Indeed, the scope and limitation of ATS litigation can be illustrated through its successes and failures. The successful Holocaust litigation cases consisted of the Swiss Gold Bank case and the Nazi Slave Labour case. In the case of In re Holocaust Victim Assets Litigation, ${ }^{98}$ a class action was brought against the three large Swiss banks, alleging that they had violated international law by knowingly retaining and concealing the assets of Holocaust victims, accepting and laundering illegally obtained

93 Bachmann "Where do we stand with human rights litigation against corporations?" 2007 TSAR 292; Herz "The Liberalizing Effects of Tort: How Corporate Complicity Liability Under the Alien Tort Statute Advances Constructive Engagement" 2008 Harvard Human Rights J208.

94 I USC $\S 1$.

95 Citizens United v Federal Election Commission 558 US 310.

96 Santa Clara County v Southern Pacific Railroad 118 US 394.

97 Strydom \& Bachmann "Civil liability of gross human rights violations" 2005 TSAR 448 454-457; "Shell on trial - Oil giant in the dock over 1995 murder of activist who opposed environmental degradation of Niger Delta" The Independent (2009-15-26) available at http://www.independent.co.uk/news/ world/americas/shell-on-trial-1690616.html (accessed on 2012-04-24); John Doe I v Unocal Corp 403 F 3d 708 concerned allegations of corporate complicity in forced labour and torture (the case was settled out of court in 2006); "Historic advance for universal human rights: Unocal to compensate Burmese villagers" http://www.earthrights.org/news/press_unocal_settle. shtml (accessed on 2012-04-23); Wiwa v Royal Dutch Petroleum Co 226 F $3 \mathrm{~d} 88$ (the case was based on the alleged involvement of the Royal Dutch/ Shell oil group in human rights abuses in Nigeria, leading to the 1995 torture and murder of the environmental and community activist Ken Saro-Wiwa and was settled out of court in 2009); Sarei v. Rio Tinto PLC 487 F 3d 1193 (regarding alleged complicity of corporations in the commission of war crimes committed by Papua New Guinean Security Forces).

$98 \quad 105$ F Supp 2d 139. 
Nazi loot and transacting in the profits of slave labour. The case was never decided in court but led to a $\$ 1.25$ billion settlement in $1998 .^{99}$ This perhaps shows the main impact of the ATS: corporate defendants were driven to settle out of court, instead of risking an adverse judgment at trial. A settlement, whilst not apportioning blame, does at least provide monetary reparations, which of course would be what is awarded in a successful tort claim.

The second case, In re Nazi Era Cases Against German Defendants Litigation, ${ }^{100}$ was a class action against German corporations for their alleged complicity in the Holocaust by using slave labour in their production lines during World War II. Again showing the potential of the ATS to lead to reparations for those wronged parties, this highly politicised case ended with a settlement in 1999 when the defendant corporations and the German government agreed to establish a jointly funded $\$ 5$ billion foundation for compensating the surviving victims of Nazi slave labour.

These successes led many more extraterritorial claims to be filed. These have included the Herero Reparation cases and the still ongoing Apartheid lawsuits. ${ }^{101}$ It is these lawsuits which reveal the uncertain future the ATS litigation faces.

Acts of genocide, crimes against humanity as well as slavery were committed by the German Empire against the nations of the Herero, ${ }^{102}$ the Great Namaqua, Boschmans and Hill Damaras in its former colony German South West Africa in the late nineteenth and the early twentieth century. ${ }^{103}$ These acts were the subject of reparation lawsuits brought before US Federal Courts in 2004. The Hereros sued Deutsche Bank and the Deutsche Afrika-Linien Gmbh \& Co shipping line (as the legal successor to the former Woermann Line), for alleged participation in crimes against humanity, genocide, slavery and forced labour. ${ }^{104}$

The plaintiffs failed to convince the Court to recognise US jurisdiction for a private cause of action for violations of customary international law. ${ }^{105}$ In short, the ATS was found to be inapplicable. We can see in this judgment a key formal virtue of the rule of law: namely legal certainty.

99 Stephens 543.

100198 FRD 429 (DNJ) MDL No 1337 DNJ Lead Civ No 98-4104 (WGB) (2000).

101 Stephens $543 \mathrm{ff}$ for an overview of related lawsuits within their topical context; In re South African Apartheid Litigation 02 MDL 1499 (SDNY) 2009 continues the original unsuccessful 2004 lawsuit; In re South African Apartheid Litigation 346 F Supp 2d 538.

102 See Anderson for a summary of the political and legal questions surrounding the Herero's cause of action against Germany.

103 Krüger "Coming to Terms with the Past" (2005) 45-49; Erichsen \& Olusoga The Kaiser's Holocaust: Germany's Forgotten Genocide and the Colonial Roots of Nazism (2010).

104 BBC News "German bank accused of genocide" (2001-09-25) http:// news.bbc.co.uk/1/hi/business/1561463.stm (accessed on 2012-04-20).

105 Herero People's Reparations Corp v Deutsche Bank AG 370 F 3d 1192; Stephens 1194-1195. 
Such a position assumes that to open up US Courts to all potential extraterritorial claims would render the law uncertain and completely indeterminate. There would be no real limiting principle with which to determine claims. Despite this failure, the topic of restitution and rehabilitation for Germany's colonial crimes remain important to the peoples of Namibia. ${ }^{106}$

The consequences of South African Apartheid are a clear example in showing exactly why the ATS litigation has been favoured by non-US citizens who wish to claim reparations for past wrongs. South Africa established in 1995 the Truth and Reconciliation Commission (TRC) to investigate and record the human rights abuses which occurred under Apartheid. Under certain circumstances, the TRC could grant immunity from prosecutions in the form of individual amnesty. ${ }^{107}$ Chaired by former Archbishop Desmond Tutu, the TRC's main purpose was to contribute to South Africa's transitional peace building by emphasising reconciliation and rehabilitation over criminal prosecution. ${ }^{108}$ One of its declared objectives was to use reparation as a form of moral and legal rehabilitation. ${ }^{109}$ This was to be achieved by securing payment of reparations directly to individual victims and/or their relatives through a state-run reparation scheme for the compensation of as many as 22,000 victims. ${ }^{110}$ The TRC recommended the establishment of a fund worth R2.8 billion for the payment of final reparations to the victims of apartheid.

Whether the TRC managed to exceed in respect to all expectations set in it will remain open to debate. ${ }^{111}$ What remains beyond doubt is the fact that the failure of two consecutive South African governments to implement the TRC's recommendations regarding individual monetary compensation has undermined the original objective of the TRC to

106 Hoffmann "German Acknowledgments A Milestone in Our Struggle" The Namibian (2012-04-12) http://www.namibian.com.na/columns/full-story/ archive/2012/february/article/german-acknowledgments-a-milestone-in-ourstruggle. (accessed on 2012-04-20).

107 Promotion of National Unity and Reconciliation Act 34 of 1995.

108 Justice in Transition booklet explaining the role of the TRC http:/l www.justice.gov.za/trc/legal/justice.htm, (accessed on 2012-04-23).

109 TRC A Summary of Reparation and Rehabilitation Policy, Including Proposals to be Considered by the President http://www.justice.gov.za/trc/ reparations/summary.htm (accessed on 2012-04-20); Truth and Reconciliation Commission of South Africa Report Volume 5 (2003) ch 5 , 173-195 http://www.justice.gov.za/trc/report/finalreport/Volume\% 205.pdf (accessed on 2012-04-20) and Preamble Promotion of National Unity and Reconciliation Act 34 of 1995.

110 Bachmann Civil Responsibility For Gross Human Rights Violations - The Need For A Global Instrument (2007) 40-43.

111 Truth and Reconciliation Commission of South Africa Report Volume 1 ch 1 , where the chairperson sums up some of the criticisms and challenges directed at the TRC during the duration of its work http://www.justice.gov.za/ trc/report/finalreport/Volume\% 201.pdf (accessed on 2012-04-20). For a current summary, see South African Coalition for Transitional Justice (SACTJ) "Background: Facing Apartheid's Legacy" http://ictj.org/our-work/regionsand-countries/south-africa (accessed on 2012-04-20). 
rehabilitate the victims of the days of the Apartheid struggle. ${ }^{112}$ The 2011 plan of the government to make provision for the payment of educational assistance and health benefits for the victims of apartheid and their children was regarded by many activist groups as being too superficial and not in the spirit of the TRC's original aims. ${ }^{113}$ Consequently, The Khulumani Support Group of Apartheid Victims called upon President Jacob Zuma to honour the obligation to implement all of TRC's recommendations. ${ }^{114}$

This failure to implement a proper reparation disbursement policy in a timely fashion failed to close an accountability gap which prepared the way for the later Apartheid litigation cases. In re Apartheid Litigation refers to an ongoing litigation arising from the alleged collaboration of US and international MNC's with the former South African Apartheid government in committing international human rights violations by aiding and abetting its military and security apparatus.

Originally brought as a class action in 2002, the original lawsuits targeted twenty corporate defendants. ${ }^{115}$ Dismissed in 2004 by the US District Court for the Southern District of New York on grounds of lack of subject matter jurisdiction under the ATS, the cases were allowed to proceed on appeal in 2009, albeit against a reduced number of defendants, namely Daimler, Ford, General Motors, IBM and Rheinmetall Group. ${ }^{116}$

The Apartheid cases illustrate the complexity of addressing historical claims and the wider repercussions for states affected. South Africa is the perpetrator state as well as the country of the victims, and also the host state to many corporate defendants and therefore depending on such Foreign Direct Investment. The South African government under former President Mbeki opposed the litigation and filed amicus curiae papers

112 Neither former president Thabo Mbeki nor President Jacob Zuma showed much interest in implementing the TRC's recommendations. The only exception was the initial disbursements of R48.37 million by Nelson Mandela's President's Fund, which paid out grants of R3,000 each to the 17,100 applicants in November 2001. The median annual household income in SA at that time was around R21,700; Strydom \& Bachmann 2005 TSAR 448 466-467.

113 South African History Archive Draft Regulations released for payment of reparations to apartheid victims (2011) http://www.saha.org.za/news/2011/ May/draft_regulations_released_for_payment_of_reparations_to_apartheid_ victims.htm (accessed on 2012-04-23). The South African Coalition for Transitional Justice criticised these regulations in its Comments on The Draft Regulations Published By The Department of Justice Dealing With Reparations For Apartheid Era Victims (2011) http://ictj.org/sites/default/files/ SACTJ-South-Africa-Reparations-Submission-2011-English.pdf (accessed on 2012-04-23).

114 "Khulumani Memorandum to the President" (2012) http://www.khulumani. net/reparations/corporate.html (accessed on 2012-04-23).

115 In re South African Apartheid Litigation; Ntsebeza v Citigroup 346 F Supp 2d 538; Bachmann 34-36.

116 In re South African Apartheid Litigation 02 MDL 1499 (SDNY) 2009. 
accordingly. ${ }^{117}$ This opposition was withdrawn under President Zuma in 2009, when support for hearing such a case before a US court was made public. ${ }^{118}$ Again showing the effect of the ATS, General Motors settled the case in 2012 by compensating 25 plaintiffs. ${ }^{19}$

The South African Apartheid litigation under the ATS has the potential, together with the failed Herero litigation, to serve as an indicator to how successful a future lawsuit against the UK for their concentration camp policy in South Africa could be. However, the ATS litigation which has reached the Supreme Court points to a less optimistic outlook for such extraterritorial claims, based in part upon a formal construction of the rule of law.

Sosa ${ }^{120}$ involved a claim by a Mexican citizen against another Mexican citizen for a kidnapping that occurred in Mexico. While accepting that federal courts did have jurisdiction over torts in violation of the "law of nations", 121 the Court strictly limited the category of offences which were defined by their universal acceptance, their obligatory nature and high degree of specificity. ${ }^{122}$ Thus the Court had the rule of law in mind in ensuring certainty of the common law. Indeed this view is reinforced by the fact that the Court contended that a cause of action which satisfies the first three heads can still be non-justiciable if prudential considerations such as public policy weigh in favour of nonjusticiability. ${ }^{123}$

This limitation upon ATS litigation could be in the process of being extended. In Kiobel, ${ }^{124}$ the question posed was whether corporate civil tort liability under the ATS was justiciable, or whether corporations were immune for tort liability. During oral argument, Justice Alito expressed concern at the very extraterritorial nature of the ATS:

The first sentence in your brief in the statement of the case is really striking: 'This case was filed ... by twelve Nigerian plaintiffs who alleged ... that respondents aided and abetted the human rights violations committed against them by the Abacha dictatorship ... in Nigeria between 1992 and

117 This decision was taken in order to prevent any damage to present and future foreign investment in South Africa and must be seen before the background that the original amount of remedies sought, totalled US $\$ 400$ billion. "It's state v apartheid victims" Mail \& Guardian (2005-10-21) 5 for a brief overview of the controversy in South Africa.

118 "State supports apartheid-era victims" IOL - News for South Africa (2009. 09-03) http://www.iol.co.za/news/politics/state-supports-apartheid-era-vic tims-457265? ot = inmsa.ArticlePrintPageLayout.ot (accessed on 2012-0423)

119 Ephraim "US General Motors settles apartheid reparations claim” Mail \& Guardian Online (2012-02-29) http://mg.co.za/article/2012-02-29-us-generalmotors-settles-apartheid-reparations-claim (accessed on 2012-04-24).

120 Sosa $v$ Alvarez-Machain 542 US 692.

121 Ibid 714.

122 Ibid 732.

$123 \mathrm{Ibid}$.

124 Kiobel v Royal Dutch Petroleum 2012 (SCOTUS). 
1995. What does a case like that - what business does a case like that have in the courts of the United States? ${ }^{125}$

Justice Alito thus clarifies the Court's concern in Sosa - why should offences committed abroad be justiciable in American courts? Do prudential considerations (ensuring certainty in the law) disqualify such extraterritorial actions? This concern for key principles of the rule of law led the Supreme Court to order Kiobel to be expanded and reargued. The new question the Court will answer is:

Whether and under what circumstances the Alien Tort Statute, 28 USC § 1350 , allows courts to recognise a cause of action for violations of the law of nations occurring within the territory of a sovereign other than the United States. ${ }^{126}$

Thus the potential of extraterritorial historical justice litigation may be curtailed through a concern to secure legal certainty and the rule of law. The future of historical justice litigation may have to focus upon territorial challenges.

\section{Australia: Native Title, Mabo and Beyond}

The Australian response is one which Justice Alito may deem as most suitable for such historical justice litigation: through the State in question allowing such claims, the rule of law, and the legal certainty which forms a part of the rule of law, are maintained.

In Mabo, ${ }^{127}$ the High Court of Australia had to decide whether "native title" existed in Australian law, 100 years after Cooper v Stuart ${ }^{128}$ denied that such title existed. The High Court faced head on the traditional narrative of Australia: the doctrine of terra nullius. Most interestingly, terra nullius was not mentioned in the first 183 years of Australian jurisprudence, nor mentioned before the Court in oral argument. ${ }^{129}$ The first description of Australia as terra nullius occurred in a 1979 case, Coe $v$ Commonwealth. ${ }^{130}$ There, the High Court held that Australian sovereignty, founded upon terra nullius, was not justiciable in Australian courts. The High Court in Mabo thus declared that they were faced with a choice. Either they could apply the existing authorities and deny that Aboriginals had rights to land, or overrule those cases. ${ }^{131}$

For Brennan J, delivering the leading judgment, overruling the cases was necessary as otherwise their authority would destroy the equality of

125 Kiobel oral transcript 11 http://www.supremecourt.gov/oral_arguments/ argument_transcripts/10-1491.pdf (accessed on 2012-04-23).

126 See http://sblog.s3.amazonaws.com/wp-content/uploads/2012/03/10-1491 order-rearg-3-5-12.pdf (accessed on 2012-04-23).

127 Mabo v Queensland (No 2) 1992175 CLR 1 (HCA).

128 Supra.

129 Ritter 22.

130 Coe v Commonwealth 197953 AJLR 403 (HCA).

131 Mabo par 39. 
all Australian citizens before the law. ${ }^{132}$ Brennan J argues passionately for equality and justice under the law, values buttressing the rule of law. Crucially, Brennan J contended that Mabo presented the Court with a fundamental clash of principles. First was the fact that the dispossession of the Aborigines underwrote the development of the Australian nation. ${ }^{133}$ Second, the Court argued that it could not adopt rules if those rules would fracture the skeleton of principle that gives the law its shape and internal consistency - the rule of law. ${ }^{134}$

What is most important here is that terra nullius was treated by the Court as a foundational legal principle, when the reality of Australian colonialism was that it was no such thing. The denial of Aboriginal land rights was not based on a legal doctrine, as Reynolds would have it, but upon the brute assumption that Aboriginals were savages without civilisation. Aboriginals were "physically present, but legally irrelevant". ${ }^{135}$

Thus the High Court created a conflict in relation to the rule of law. By treating terra nullius as the founding legal doctrine of the Australian legal system which dispossessed Aborigines, they ensured that the rejection of terra nullius would be seen as evidence of the progress of the law. ${ }^{136}$ Thus the Court couched its judgment in the language of reconciling the (fictional) foundational act of dispossession with the (fictional) fact that this act was the condition of the ongoing existence of Australia.

The Court distinguished between the acquisition of sovereignty and the consequences of the acquisition of sovereignty. The former, held the Court, is not subject to review by the Court as it is that sovereignty that gives the Court power to rule on the matter at hand. The latter issue was justiciable. From this the Court held that the Crown gained title to Australia through the act of terra nullius, in other words, the Crown gained the right to create property rights but where none had been created it was possible for native title to continue to exist. ${ }^{137}$ This right was entrenched in the Native Title Act 1993. ${ }^{138}$ In this way, Aboriginal communities could gain land rights if they could show that they had "continual association" with the land from the time of colonisation.

This adherence to the certainty of the legal system, part of the rule of law, was in fact a "symbolic legitimation ritual". ${ }^{139}$ The right to native title is curtailed by the rule of law in a manner different to the legislation in the United States. The formal adherence to the rule of law here involves the application of general principles ("native title") and treating

132 Ibid par 63.

133 Ibid par 82.

134 Ibid parr 28-29.

135 Simpson "Mabo, International Law, Terra Nullius and the Stories of Settlement: An Unresolved Jurisprudence" 1993 Melbourne U LR 200.

136 Ritter 30.

137 Mabo par 55.

138 Native Title Act 1993 (Cth) (NTA).

139 Simpson 207. 
like cases alike. ${ }^{140}$ However, this formal legal equality is tied to the concept of the legal person. ${ }^{141}$ Kerruish and Purdy ${ }^{142}$ have stated that this means that people are free (stripped) of all their characteristics. Equality at law has this dual freedom: all those who come before the law are equally stripped of their actual characteristics and equally presumed to be responsible for their actions. In the case of Mabo, by assuming that Aboriginals are free actors, the law misdescribes the historical reality of racism and discrimination, but does so in a way that legitimises the overlooking of this fact - namely formal equality under the rule of law. The gains of Mabo were achieved within the supremacy of the liberal, Anglo-American rule of law framework. ${ }^{143}$

What is more concerning for the question of redress for past wrongs, the High Court ruled that the original act of sovereignty was not justifiable in the court system. By refusing to engage with terra nullius, itself a fiction, the court not only legitimises its jurisdiction, but actually legitimises the very act of dispossession that was based upon a colonial racism. As Coe ${ }^{144}$ stated, the High Court, in rejecting terra nullius, "threw away a name but retained the substance". Terra nullius still provides the foundation of the Australian state, meaning that Aboriginal dispossession is now legally set in stone, but is perversely legitimated by the claim that the law is acting in a non-discriminatory manner. Things were changed in order for things to remain the same. ${ }^{145}$

\section{Conclusion}

This article has explored the potential and pitfalls of historical justice litigation with reference to two instances of British colonialism: Australia and South Africa. Formal constructions of the rule of law, with their emphasis upon legal certainty, have curtailed the search for justice on the part of victims of human rights litigation. In Australia Aboriginals have to defer to the supremacy of the European common law, and ignore past injustices in order to have their rights to land legitimated by the same system of law which legitimated their very dispossession. In South Africa, the failure of the government to provide adequate reparations to victims of Apartheid has led to individuals starting extraterritorial litigation under the ATS. However, even here formal conceptions of the rule of law have led the US Supreme Court to seemingly narrow, and possibly even foreclose the options for aliens to bring claims. In order to bring about the very historical justice that marks both these forms of litigation, courts will have to construct a substantive conception of the rule of law, which

140 S 225 NTA; MacCormick Legal Reasoning and Legal Theory (1978).

141 Weyraucht "Law as Mask - Legal Ritual and Relevance" 1978 California LR 699.

142 Kerruish \& Purdy “He 'Look' Honest, Big White Thief” 1998 Law, Text, Culture 150.

143 Ritter 32.

144 Coe \& Lewis “100\% Mabo” 1992 Polemic 143.

145 Ritter 33. 
values the rectification of human rights abuses above legal certainty. It is with this uncertain conclusion that this article ends. 